Original Research Paper

\title{
Exploring the Inadequacy of Pertinent Capacities for Urban Flood Risk Management in the Developing Countries
}

\author{
${ }^{1}$ Nkwunonwo Ugonna Chimnonyerem, \\ ${ }^{1}$ Chiemelu Emmanuel Ndukwe and ${ }^{2}$ Nkwunonwo Ugochi Adannaya \\ ${ }^{1}$ Department of Geoinformatics and Surveying, University of Nigeria Enugu (UNEC), Nigeria \\ ${ }^{2}$ Transport Section, Portsmouth City Council (PCC), Portsmouth, United Kingdom
}

Article history

Received: 23-03-2016

Revised: $10-07-2016$

Accepted: 18-08-2016

Corresponding Author: Nkwunonwo Ugonna

Chimnonyerem

Department of Geoinformatics and Surveying, University of Nigeria Enugu (UNEC), Nigeria

Email: ugonna.nkwunonwo@unn.edu.ng

\begin{abstract}
Of all the widespread natural hazards with large scale human, economic and environmental impacts, flooding surpasses. In the urban areas, the threats of this hazard are substantial and call for ever more attention, which, within the contexts of sustainable human and urban development, is increasingly an important problem in social science research. Urban flooding is a relatively new hazard phenomenon, which is progressively galvanising significant concerns globally due to the economic and political significance of cities. Flood risk management, based on the UNISDR idea of living with floods rather than fighting them, provides systematic techniques for tackling this hazard. However, the insufficiency or lack of the pertinent capacities, which are fundamental to best practices in flood risk management, undermine these techniques in many developing countries (DCs), such as Nigeria and Bangladesh. This study, through a desktop review of various published materials, focusing on urban flooding and management experiences in Lagos, Dhaka and Maputo, explores the lack of these capacities. Among other issues, the idea of resilient cities and communities as well as sustainable urban development will be realistic in the DCs only if adequate attention is given to capacity development.
\end{abstract}

Keywords: Flooding, Natural Hazards, Hazard Impacts, Urban Flooding, Urban Areas, Pertinent Capacities, Developing Countries, Flood Risk Management, UNISDR, Resilience, Sustainable Development

\section{Introduction}

Throughout history, every act of human development has a price, which is increasingly an important problem within social and sustainability sciences research. For example the two world wars (WW1 and WW2) were the price for growth in political interactions and interests, militarism and territorial integrity among the world powers (Lyons, 2009). Climate change as seen today is a price for industrialization and technological growth especially within the last four decades. Terrorism, according to few studies in the social sciences such as those of (Newman, 2006; Freeman, 2008; Krieger and Meierrieks, 2011), is possibly a price for self-awareness for some individuals who seem to act under the pretext of fighting for social and political justice. Oddly, the belief that religious fanaticisms is a way of finding fulfilment and happiness in life and "righting the wrongs in a particular history" seems to drive some people to prohibitive limits. Indeed, end often justifies the means. However, taking human lives and causing political and social instabilities just to justify a religious, ethnic or political motive are unimaginable and beyond acceptable norms. It simply cam imply that some of the pathways to self-awareness and self-emancipation are misdirected and totally misguided.

Parallel to terrorism, climate change and the two global wars is urban flooding-the focus of this investigation-which can be considered as a price for economic development and the rise of concrete world in the modern-day cities. Urban flooding occurs when water overflows land areas and properties in a built-up environment (Fig. 1). It remains a major environmental hazard that affects many cities across the world, although the rapidly evolving, more densely populated urban areas in Developing Countries (DCs) are disproportionately threatened (Jha et al., 2012). The flooding of New Orleans USA in 2005, flash flood that affected many cities within England and Wales in 2007, the catastrophic floods of 2010 in Hong Kong and the Dhaka floods of 2012 are few recent examples. 

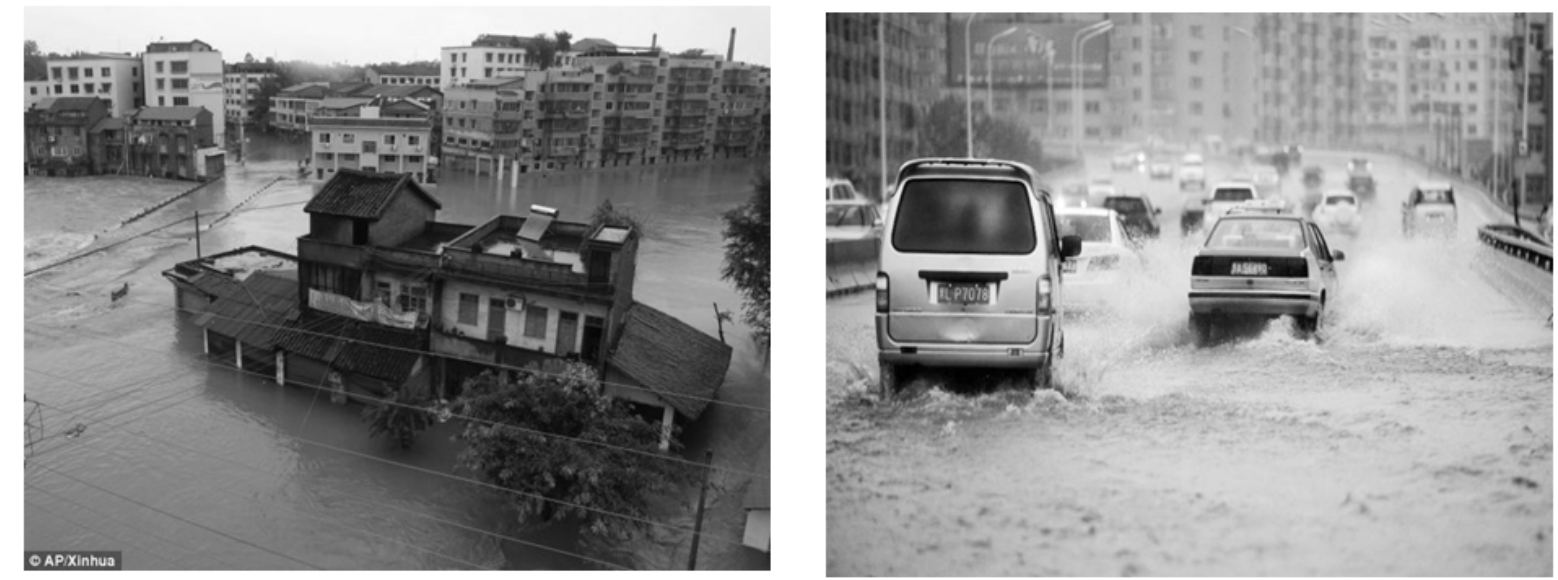

Fig. 1. Examples of urban flooding. The left-side picture shows an area with blocks of houses submerged and residents displaced. The right-side picture shows a major read inundated. Cars have difficulty travelling under such situation. Source: Ecns.cn (2016)

Within natural hazard framework, urban flooding is a relatively new phenomenon when compared to coastal and fluvial flooding. Due to high concentration of people and assets in cities, its human and economic impacts are significant (Chen and Ravallion, 2007).

Urban flooding is particularly a challenging hazard to address due to the multifaceted nature of the underlying factors (Dawson et al., 2008). Many strategies to address the challenges of urban generally are based on the UNISDR philosophy of flood risk management (UNISDR, 2010). In many developed societies including the US, UK and the rest of Europe, it is certain a number of capacities, which in this research are referred to as 'pertinent capacities', are required to address the challenges of urban flooding and they appear to be enshrined in regional and national flood management policies (Merz et al., 2007). For example the European commission flood directive enshrines the mapping of flood hazard and risk as a capacity for the development of regional flood risk management policy. In England and Wales, sustainable urban drainage system is a strategic capacity for a national flood risk management (Pitt, 2008). However, in the many DCs, these capacities are generally lacking. Whilst this situation often causes severe limitations in the current approaches to tackle urban flooding in the DCs, it creates a significant gap in the literature relating to the science of flood risk management.

Against this background, the main aim of this study is to investigate the limitations in flood risk management in the urban areas of DCs, focusing on Lagos, Maputo and Dhaka. Drawing from flood risk management in the more developed societies, such as the US, UK and the Netherlands, the authors addressed the following specific objectives:
- Identify those relevant capacities, which characterise an ideal flood risk management, but which are lacking in the DCs

- Relate the situation of paucity of relevant capacities in the DCs to limitations in the management of urban flooding in such areas

- Make possible recommendations towards a more proactive management of present and future urban floods in the DCs

This study provides significant bases for future research in the field of social sciences, given the obvious implications of the impacts of urban flooding on the social and economic development of cities and societies. Whilst the physical, economic and emotional impacts of urban flooding on social systems are considerable, a possible remedy to the hazard only ensures that the risk to social systems is mitigated. Hypothetically, the range of capacities that provide such a remedy are underpinned by research within the core of physical sciences, such as hydrology and engineering, but social policy, economics and political structures are also indispensable. The synergistic effect of these areas of study in flood risk management is significant. However, considering the centrality of social systems in the purpose, design and application of these capacities, attention to social science debates becomes an increasingly research issue. Thus, exploring these capacities, especially attempting to understand their variations across various spatial and temporal frameworks, as well as the theoretical underpinnings, to provide the direction and motivation for qualitative and more empirical research towards addressing the human and ecological impacts of urban flooding is of significance within social sciences context. 


\section{Methodology}

This study employs a desk research method in which several literature search processes were undertaken, to identify the existing studies relating to the concepts of 'flooding' and 'flood risk management'. Firstly, a body of literature focusing on a general overview of the concepts was identified. Secondly, specific locations of interest to the present study (i.e., Lagos, Maputo and Dhaka) were sorted out from the overall identified literature. The vast majority of the literature were sourced from mainly Google Scholar, as many publications nowadays are open source and Google Scholar referenced. There were other materials accessed from major databases and national documentaries. For the online sorting, combination of terms for flooding such as "flooding and management in Lagos Nigeria", "flooding and management in Maputo, Mozambique", "flooding and management in Dhaka Bangladesh" was found relevant to the research. In line with academic regulations and standard on ethics and scientific quality, the authors assigned more weight to articles published by Elsevier, Science Direct, Taylor and Francis, Wiley and sons, American Society of Civil Engineers (ASCE), Nature, Sage, Science publishers, Copernicus and Springer publishers and on well acknowledged international conferences, although locally published journals provided most of the information to establish the case of the study. The data that provided much of the evidence regarding the prevalence of flooding in the case studies were sourced from EM-DAT. These findings are reported in the subsequent sections.

\section{Results and Discussion}

\section{Urban Flooding: Meaning and the General Context}

In its simplest sense, urban flooding typically refers to the overflow of water into cities, resulting in large scale impacts. This is often as a result of the multifaceted combination of physical processes, anthropogenic activities and the complex geomorphological nature of urban terrains (Sampson et al., 2013). In many studies such as (Douglas et al., 2008; Djordjevic et al., 2011; Meesuk et al., 2015), four types of urban flooding can be recorgnised. (1) Localized flooding which is common in slum areas due to insufficient drainage facilities, obstruction of available drains and culverts by waste and debris, as well as reduced gaps between dwellings which causes pathways to become streams after heavy rain. (2) Flooding from small streams whose catchment areas lie almost entirely within built-up areas. (3) Flooding from major rivers whose floodplains are important locations of most towns and cities. (4) Coastal flooding which is when flood waters from seas inundate exposed coastal land due to low elevation of the areas.
Despite the typology being considered, the generality of urban flooding suggests three important factors: Climate change, which causes more frequent and intense rainfall; poor urban planning and the rapid population growth and urbanization (Fig. 2) (Kundzewicz et al., 2014). A vast pile of evidence exists to support the reality of climate change and its effects on global precipitation (Walther et al., 2002; Dore, 2005; Marvel and Bonfils, 2013). According to global rainfall databases, there is a significant variation in the intensity and frequency of rainfall in recent times, compared to the last three decades (Chou et al., 2013). Critically, pluvial events are the main sources of hydrological input during urban flooding and whilst there are predictions of worsened future climate change scenarios, more urban flooding events are likely to be expected (Action Aid, 2006; UNISDR, 2010). This implies that capacity building and development is now an issue that flood risk managers must pay attention to in order to be able to mitigate the present and future impacts of urban flooding.

Poor urban planning and governance appears to be the primary culprit of urban flooding given the critical effects of dynamic urban activities on natural ecosystem processes including the local circulation and distribution of water resources (Alberti, 2005). Poor urban planning and governance entails the failure to address these critical effects, whilst considering the development of cities (Adeloye and Rustum, 2011). As cities grow and more people immigrate, the needs for more housing units and improved urban utilities arise, leading to increased impervious surfaces. In the DCs, some complex human activities including indiscriminate disposal of waste, blockage of drainage systems, construction on drains and failure to heed flood warning, all which seem to worsen the occurrence and impacts of urban flooding in those places are implicated (Aderogba, 2012; Min et al., 2011). A general perception is that much impervious surfaces reduce infiltration of water into the soil and increase surface water runoff and time to peak (Fig. 3 and 4) (Weng, 2001; DeFries and Eshleman, 2004). Sufficient drainage system often aids the evacuation of this excess water. But due to poor urban planning, a limitation or insufficiency of drainage facilities prevails in many urban locations and this is an important issue of debate within urban flood risk management.

Rapid population growth and urbanization are major issue of debate within the global context of urban flooding. It is estimated that more than half of the world's population are presently residing in urban areas and could go up to about $70 \%$ by 2050 (Un-Habitat, 2008). In England and Wales, 80,000 homes are at risk of urban flooding, which is estimated to costs about $£ 270$ million (approximately US\$ 490 million) a year and could rise to between $£ 1-10$ billion (approximately US\$ $1.5-15$ billion) by 2080 (POST, 2007). About $80 \%$ of the U.S. population resides in urban areas. 


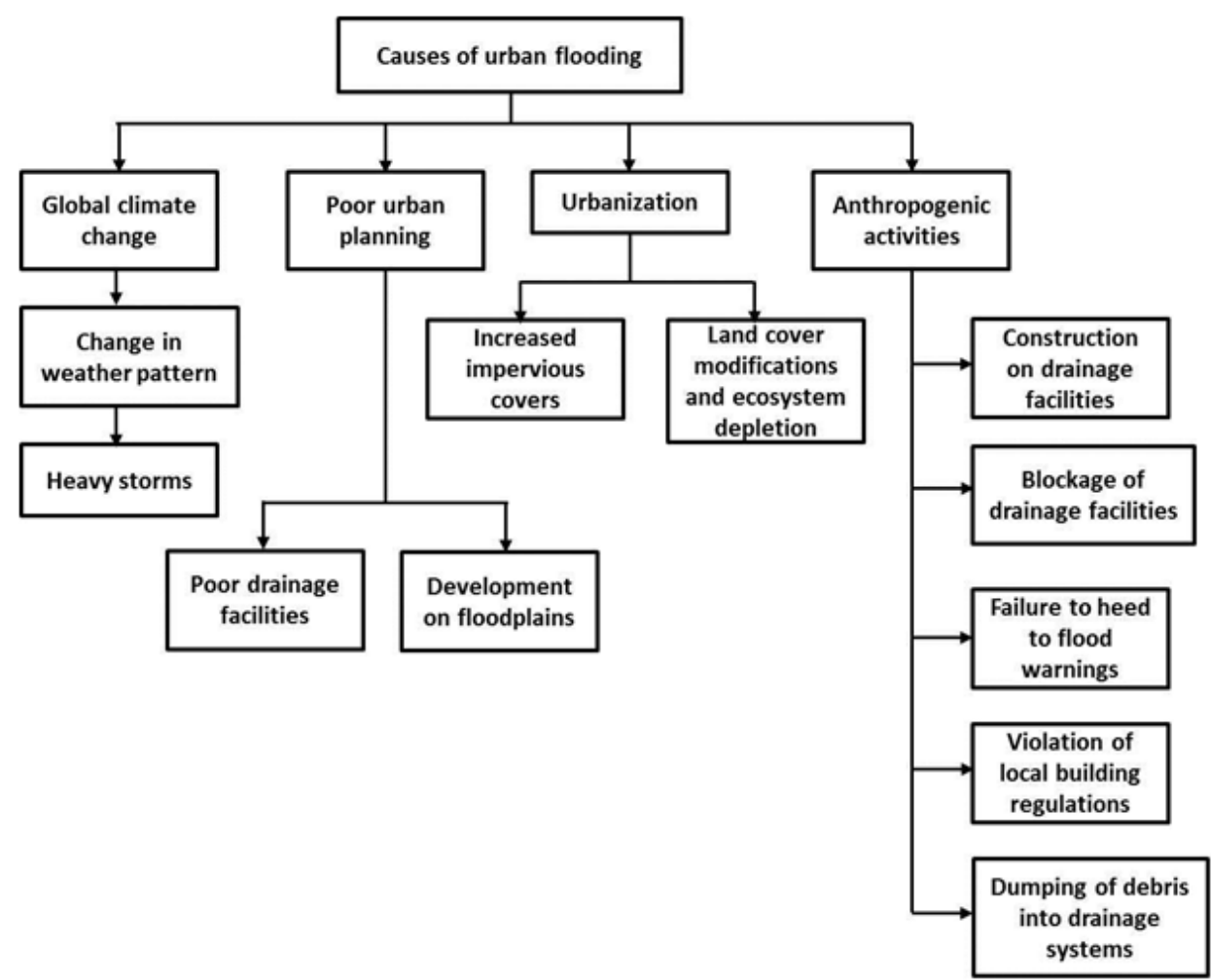

Fig. 2. Main causes of urban flooding showing global climate change, poor urban planning, urbanisation and anthropogenic activities. Source: Nkwunonwo et al. (2016)
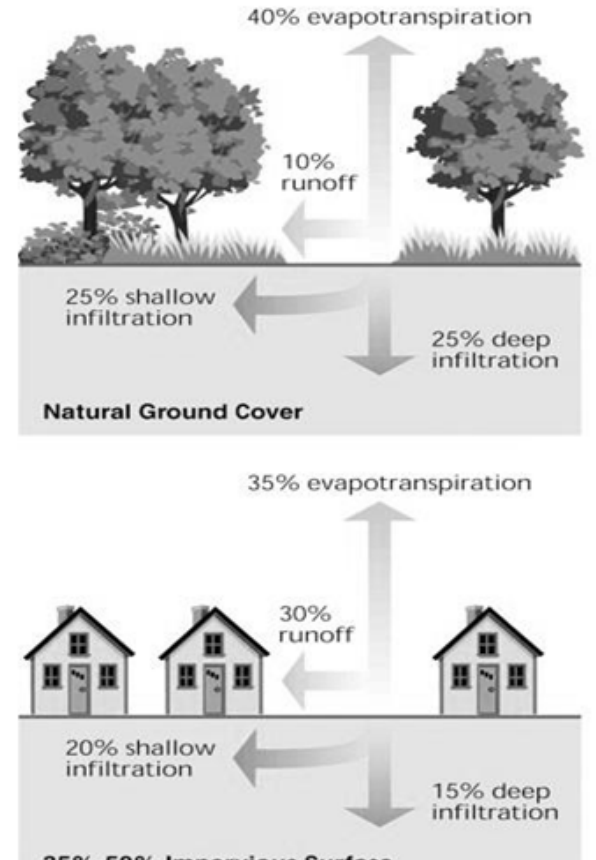

$35 \%-50 \%$ Impervious Surface

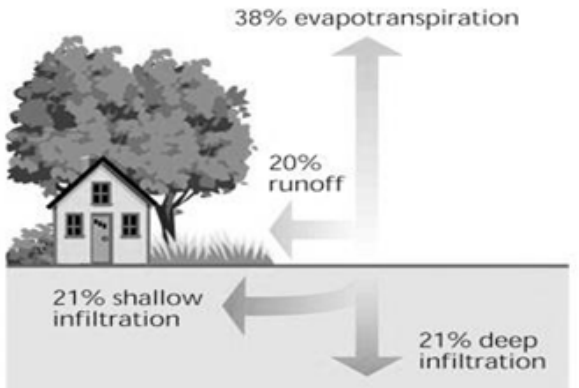

$10 \%-20 \%$ Impervious Surface

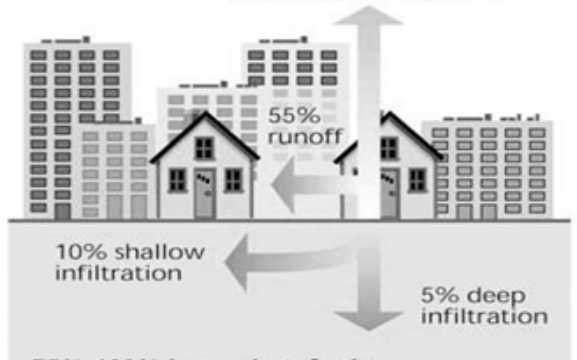

$75 \%-100 \%$ Impervious Surface

Fig. 3. The effects of urbanisation (impervious cover) on local hydrology (runoff). For a natural ground cover, only $10 \%$ runoff occurs. Between $10-20 \%$ impervious cover, about $20 \%$ runoff will occur. $30 \%$ runoff will be the case when the impervious cover is between $35-50 \%$, while $55 \%$ runoff occurs for $75-100 \%$. Source: USEPA (1983) 

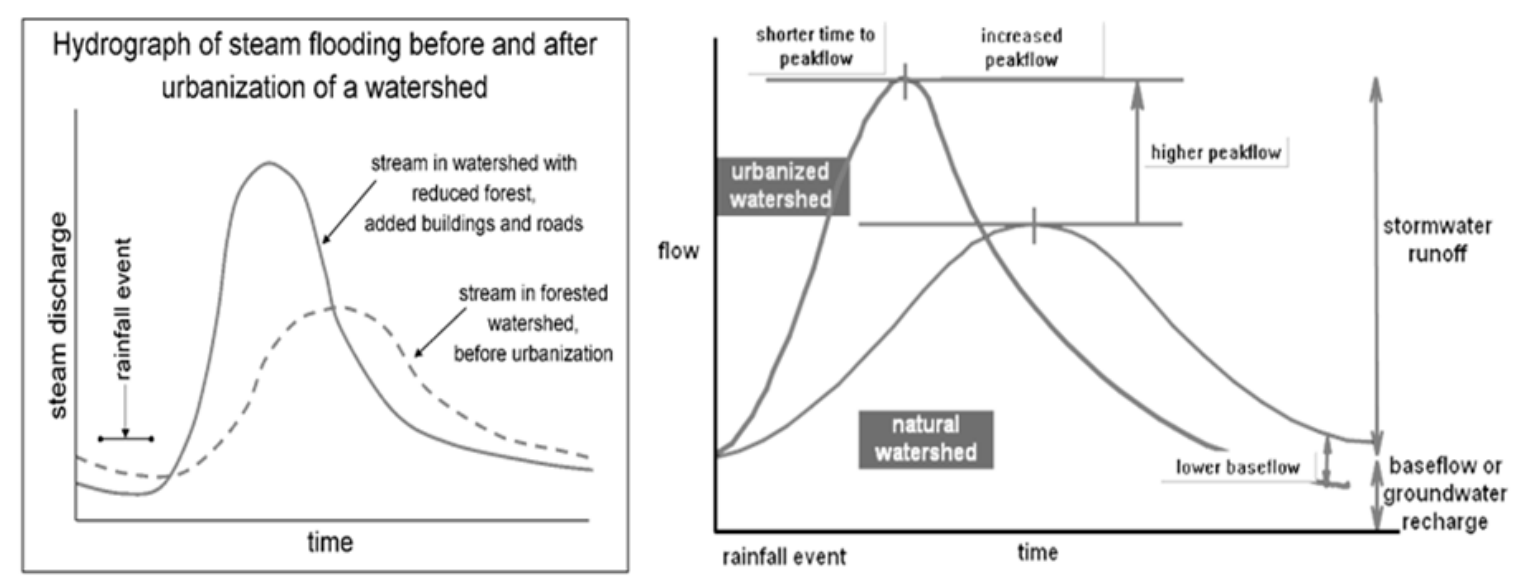

Fig. 4. The relationship between urbanisation and discharge hydrographs. The pressure of urbanization increases the peak and reduces the time of peak. Source: USEPA (1983)

Approximately 7 million urban residents in the People's Republic of China are presently exposed to urban flooding of coastal origin while about US\$ 250 billion worth of assets are at risk in the Netherlands (Nicholls et al., 2008). India, Japan and Nigeria are examples of countries in the DCs having many cities each with more than a million people residing. Although the present population in Dhaka city of Bangladesh exposed to urban flooding of coastal origin is nearly a million, more than 11 million people will be exposed by 2070 (Nicholls et al., 2008).

These statistics give a cross sectional idea of the potential risk of urban flooding. However, a clearer picture shows that the risk of urban flooding is in the form of direct, indirect, tangible and intangible losses defined on the bases of physical contact with flood hazard and the possibility of associating monetary values to losses (Smith, 2013; Merz et al., 2010a). Without downscaling the sources, these losses include but not limited to mortality, physical injuries, emotional trauma, damage to uses and household assets, loss of income, loss of employment, interruption to transport systems and economic activities. Critical to the impacts of urban flooding is present and future population residing in urban areas. Although ample research has been devoted to this issue, there remain some uncertainties regarding preparedness towards reducing the severity of the impacts of the hazard, exposure and vulnerability of social and environmental systems.

\section{Flood Risk Management: The General Perspectives}

Worsened impacts of urban flooding and how to manage them are major concern for stake holders and a key focus for research. The inexorable nature of flooding generally suggests that systematic efforts are required to address its challenges and this is what Flood Risk Management (FRM) entails. Within this perspective, attention is drawn to the idea of Disaster Risk Reduction (DRR), which the general assembly of the United Nations promotes through a number of historic initiatives and international for a. The main objective of DRR is to minimize the impacts of disasters by a critical investigation of the underlying factors (UNISDR, 2004). It focuses on three key activities. (1) Mitigation by reducing the frequency, scale, intensity and impact of hazards. (2) Preparedness by strengthening the capacity of communities to withstand, respond to and recover from hazards, lessening exposure to hazards and strategic management of land and the environment. This also involves government and implementing partners to establish speedy and appropriate interventions when the communities' capacities are overwhelmed. (3) Advocacy by positively influencing the social, environmental, political and economic issues contributing to the causes and magnitude of impact of hazards. This also involves promoting the participation of the wider population towards the means of addressing the limitations or failure of current management measures (UNISDR, 2004).

These activities underpin the idea of living with floods rather than fighting them which tends towards a policy whereby society adapts to flooding by being prepared and having the right damage reduction measures in place (van Ogtrop et al., 2005; UNISDR, 2010). This idea stems from three key considerations: (1) The limitations or failures of traditional structural flood control measures; (2) the need for a people-friendly means of addressing the challenges of flooding and (3) the goal to lessen all impacts of extreme floods while at the same time exploiting all benefits of ordinary floods (UNISDR, 2004; Di Baldassarre and Uhlenbrook, 2012). Within this framework, the concept of flood risk management provides systematic techniques for tackling all forms of flooding, whilst emphasis is placed on reducing vulnerabilities and developing the capacities of 
social systems to cope with floods through multidisciplinary approaches (Few, 2003; Schanze, 2006).

Over the years, these efforts were largely focused on fluvial and coastal flooding (Penning-Rowsell et al., 2005; Merz et al., 2010b). Despite some recent progress, urban flood risk management is not sufficiently treated. Commitments towards urban flood risk management are underpinned by the large and evolving challenge of rapid population growth, urbanization and climate changes, all of which are expected to worsen flood risk especially in the DCs (Ashley et al., 2005). For such a commitment, with overall aim being to build urban areas resilient to flooding and to ensure urban sustainability and management, a sound understanding of the source, pathways, receptors and consequences of urban flooding is essential. A vast body of literature indicates that most places especially in the Developed Countries (MDCs) such as the United States, the Netherlands, England and Wales have achieved a measure of success (Brown and Damery, 2002; Vis et al., 2003; Hall et al., 2003; Merz et al., 2007; Price and Vojinovic, 2008; Tingsanchali, 2012).

In view of urban flooding, FRM underscores the importance of accurate and actionable flood risk assessment with the aim being to reduce the likelihood and/or the impact of floods on the bases of strategies which incorporate prevention, protection, preparedness, emergency response, recovery and lessons learned (EC, 2004). These strategies require sound understanding of flooding, knowledge-based decision and strong political leadership. Therefore, integrated approaches which combine structural and non-structural measures are the bases of FRM. Structural measures are technically-based and involve channelization and the use of natural and man-made barriers to contain waters in rivers and seas. Non-structural measures are multi-disciplinary approaches such as flood risk mapping, land use zoning and planning, flood vulnerability assessment, flood proofing, flood modelling, institutionalization of policies, flood awareness campaign, flood insurance, flood forecasting, green infrastructure, relocation and resettlement plans, etc., (Smith, 2013; Merz et al., 2007; Jha et al., 2012). The European Commission directive on flooding, integrated flood risk management in England and Wales, floodplain management in the United States and flood risk and water management in Netherlands are few examples of flood risk management systems (Hall et al., 2003; EC, 2004; Galloway, 2008; Terpstra and Gutteling, 2008).

\section{European Union Commission}

In the European Commission directive on flooding, a necessary requirement for the EU member state is to prepare flood risk and flood hazard map of their country towards a regional flood hazard mapping (De Moel et al.,
2009). Flood risk and flood hazard map are necessary visual representation of flood hazard and risk essential for flood hazard communication. The maps are characterized by type of flooding, water depth, velocity and extent of water flow and can be prepared based on specified flood frequencies or recurrence interval. Common scales are 1 in 10 years, 1 in 25 years, 1 in 100 years, or the more extreme 1 in 1000 year return period floods. These are valuable aids to decision-making towards planning development activities, emergency planning and policy development. In the EC directives, collaboration, date sharing and corporate assistance are possible for member states that are threatened by flooding (EC, 2004; Merz et al., 2007). Following these directives, many European countries have been active with several measures that provide flood hazard and flood risk maps. Recently, Germany launched a project called DRIVER to facilitate the provision of radar-based imageries for flood hazard and risk covering the EU member states and other disaster threatened countries across the world (DLR, 2015).

\section{The United States of America}

Floodplain management in the United States and flood risk and water management in Netherlands are national strategies built on the ideologies of integrated flood risk management. In the United States, the management strategy arises from the awareness that much of the country's urban areas are located on or near floodplains (FEMA, 1992). As at 1992, the country encloses nearly 22000 flood prone communities (FEMA, 1992). At present, although with non-substantial evidence, the number of flood prone areas is perhaps equally significant on the basis of rapid urban growth. Reducing floodplain losses which include loos of lives and properties and loss of natural and cultural resources is the main objective of the management strategy. More than four decades ago, this strategy was in place in the United States, although a significant boost came following the 2005 Hurricane Katrina that resulted in flooding of nearly $80 \%$ of the city of New Orleans (Rykhus, 2005). Four key targets are significant in the US floodplain management strategy, which are summarised as: Adapting to flooding and its impacts on communities and individuals, reducing susceptibility to flood damage and disruption and restoring the natural and cultural resources of floodplains. The efficiency of this strategy is driven by perception and awareness of floodplain losses, knowledge, standard and technology, cascading potentials into future plans and a combination of legislative, economic, administrative and judicial opportunities, incentives and constraints that is tempered by public interest and the availability of needed information which forms the underlying framework (FEMA, 1999). 


\section{The Netherlands}

Flood risk management in Netherlands is an interesting example of commitment to build a corporate adaptation strategy. The flood risk and water management strategy combines both structural and nonstructural measures designed to protect the population within the dykes to against a $0.0001 \%$ ( 1 in 10,000 year event) (Jha et al., 2012). The country's natural topography and historical experiences of flooding are two major factors which combine to make Netherlands home of the best flood management experts in the world. With more than half of the country at or below sea level, the means of addressing human and property susceptibility to flooding are robust and clinically full proof. The 1953 severe flooding that devastated majority of the nation's economic and human infrastructure remains a major historic event. The estimated impact of the flood was 1835 deaths and one billion Dutch guilders (US\$ 558 million). The event challenged various stake holders, particularly the general public and local communities and Dutch government towards what is seen today as more effective strategies of mitigating the threats of flooding. Special effects of water management in the Netherlands include the following. (1) The commitment of the people and the government that history will not repeat itself in the country. It is claimed that flood and water management cost each adult about US\$ 100 each year. (2) Structural measures that employ some of the bests flood barriers in the world for examples delta works and dykes. (3) Flood maps that are available for different return periods to the public and are monitored and updated on a regular basis. Finally, some robust, stable, flexible and easy to use flood model (most of which are open source) and internationally recognized are developed by leading research institute, Deltares, based in the Netherlands.

\section{England and Wales}

Integrated Flood Risk Management (IFRM) in England and Wales stems from the realisation of the critical implications of climate change scenarios and urban growth. Among other factors, a synthetic definition of flooding and impacts, continuous review of management system performance, iterative decision making are key features (Hall et al., 2003). Major components of IFRM in England and Wales are Sustainable Urban Drainage System (SUDS) and clarity of institutional responsibilities and legislative acts. Following the summer 2007 floods, which affected over 55,000 properties because majority (about two-thirds) of the properties had drains and sewers which were overwhelmed, major stake holders saw the need to incorporate SUDS into flood management measures (Woods-Ballard et al., 2007; DEFRA 2013; Pitt, 2008; Butler and Davies, 2010). A SUDS is a surface water management plan designed to provide capacity for a storm event of a particular frequency. A significant feature of SUDS is the ability to increase permeability and therefore infiltration. The use of SUDS is promoted in the UK via formal building regulations, which state that 'surface water drainage should discharge to a suck away or other infiltration system where practicable' (Pitt, 2008). Clarity of legislative acts and institutional responsibilities is essential for management of flood risk at different scales and community levels. Flood and Water Management Act of 2010 assigned the strategic overview for all sources of flooding and coastal erosion to the Environment Agency and the responsibility for local flood risk was assigned to Lead Local Flood Authorities including government departments and "quangos" (quasi-autonomous, non-governmental organizations) (Pitt, 2008).

\section{Pertinent Capacities}

From the foregoing debates and on the basis of best practices that can be identified from a wide range of sources, for example (Ashley et al., 2007; Fratini et al., 2012; Sayers et al., 2013), it is undoubtable that significant progresses have been made in urban flood risk management since the last two decades. Key fundamental factors, which are herein referred to as relevant capacities include operational legislation, enhanced technology, human commitment, clearly defined institutional roles, economic buoyancy and vendible research.

\section{Social Capacity}

Social capacity is the ability of social groups or communities to work together for the purpose of caring for its members (Lichterman, 2006; 2009). The overall objective is to build a corporate adaptive capacity and corporate resilience to external stressors. Within a community, some social factors can be identified which define strength and weaknesses for different individuals and these include age, gender, socio-economic status, family structure and marital status. But is it possible that every individual within a community will have equal strength and weaknesses? On the basis of risk, this is an issue of environmental justice (Brulle and Pellow, 2006). Any arguments propagating the notion that damage must be shared equally as benefits must also embrace the possibility that perception, capacities and involvement vary among members of a community (Schlosberg, 2007). Considering these variations and on the basis of social factors, we know that in many communities there are members who have exceptional strength and others who are unreservedly weak. For these communities, the former include political office holders and owners heavy businesses while the latter mainly include the aged, infirm and children between the ages 0-14 years. Social capacity aims at reaching a technically common basis 
where extremes and outliers are insignificant. Members of a community individually and the government at large are responsible for social capacity building.

One aspect of social capacity which plays an important role in recovery from disaster especially at the community level is social asset. Nakagawa and Shaw (2004) identified that social capital and community participation are the missing link in disaster recovery. Communities with social assets and with a culture of community-based activities can participate more effectively in the speedy and successful recovery process. With regards to urban flooding, flood risk management in the DCs can be improved by the participations of communities in government interventions programmes. Community health centers, micro finance schemes, small and medium scale business are some initiatives that can promote community assets and therefore social capacity. The community can partner with the government for the actualization of these initiatives. Measures that can promote preparedness include regular 'town cries' which is a system of communication on the basis of local equipment and dialects. Awareness campaign at various community town centers should also be considered.

\section{Economic Capacity}

Economic capacity refers to financial empowerment. In view of urban flooding, economic capacity is the capital base of a society to operationalise flood risk management. Oddly, the DCs are generally referred to as low income societies (Adams and Page, 2005). Indeed, abundant human and natural resources within these places that can support national development are acknowledged. However, corruption, political weakness, resources mismanagement and high level inequality, which creates obvious gaps between the rich and the poor, are prevalent. These factors have continued to subject the DCs to extreme hardship and poverty (Ravallion, 2001; Chen and Ravallion, 2007). It is undoubtable that economic capacity and the willingness to invest into technology and skill acquisition are essential for disaster management. For example, flood modelling which is a fundamental component of flood risk and flood hazard assessment is a capital intensive procedure. Extensive economic investment is indispensable for the acquisition of high resolution input data, high-end computer hardware and up-to-date technical-know-how. But the question of funding remains a limiting factor.

Often, victims of flooding require humanitarian assistance in the form of shelter, food and clothing. Donor groups, international organizations and countries within the United Nations have offered significant support in view of these needs. However, as pointed out in (Nkwunonwo et al., 2015a), a crucial aspect of mitigating the impacts of flooding on human populations in the DCs is poverty alleviation. This has received little attention in the literature. Pre-disaster measures such as building resilient cities and communities should take precedence over in-disaster and post disaster measures. There will be fewer issues to worry about when flooding occurs if sufficient funds were available to develop the capacities of social systems to adapt to disasters. For the DCs, prioritizing job creation for many unemployed youths, provision of quality drinking water and affordable health care, food security and national security, sustainable urban drainage systems, recreational facilities, quality and affordable education are ways of achieving this objective.

\section{Research Capacity}

In this respect, the question of to what extent, quality data, technology and collaboration have been integrated into flood risk management research is fundamental. Indeed many studies have been carried out in the DCs, but quality and transferability are critical questions. Due to the lack of quality input data and efficient technology, most of these research rely extensively on global datasets, media findings and open source software (Tayeb, 2001). Epistemic uncertainties undermine the use of global datasets. Media findings are often without ethical and empirical backings. Limited calibration and technical requirements constrain the adaptation of open source software to external locations. Under the current circumstance, it can be argued that researches in the DCs are weak or insufficient to support operational flood risk management.

Best practices in flood risk management are encouraged by collaboration which is obvious in many regional flood management consortiums such as the European Commission directive on flooding (EC, 2004). This provides a platform for exchange of ideas, data and other resources. For the DCs, understanding and operationalizing the specific roles research can play in flood risk management is fundamental. However, research needs and focus must be identified and resources must be duly allocated to such areas. Agencies must be encouraged to set up foundations and grants for research. New ideas that will foster the provision and inclusion of more locally available data into research should be encouraged, while means of improving on data quality should be addressed. Best practice may not be the objective of flood risk management in the DCs. However, developing methodologies that produce results comparable to best practices should be given attention far more to provisional measures that address flood risk as they occur is the need for sustainable development. This should be borne in mind while developing research capacity in the DCs. 


\section{Political and Juridical Capacity}

Weak political will power is a major limitation to development efforts in the DCs. Good governance and democracy which entail judicious administration of the affairs of a State at all levels on the bases of economic, political and administrative authority are complicated. Thinking rationally about these issues requires recognition of the historical background of governance in some of these countries. Majority of the countries in DCs evolved from a long term dictatorship. As pointed out by (Djankov et al., 2003; Li and Resnick, 2003), under such leadership condition, a high level of corruption prevailed, while human right and the rule of law were abused. Judiciary process takes a longer time to be completed and most often offenders were not prosecuted. Due to the sloppiness of the judiciary, laws were not enforced especially when political elites were involved. Although democracy has been welcomed in these areas, it seems the old political nature has not been detached.

Flood risk management requires strong political influence and judicial capacity as can be recorgnised in the United States, United Kingdom and Netherlands for examples. There are operational legislative acts that guide the use of the environment. On the bases of the factors that drive urban flooding, legislation and judicial powers are unleashed in their fullness. There are often no partialities in terms of enforcement of laws, arrests and prosecution of those who violate these laws. The implication is that human population respect the law and recognize their boundaries and responsibilities towards environmental standards.

This is often not the case in the DCs. However, to build the political and juridical capacity in the DCs would require a renewed ideology and commitment for change. Political leaders must learn to respond to the needs of the society not just on the basis of party agenda, but on clearly defined goals that will move the society forward. Participatory politics which ensures that the people have a stake on what is achieved in governance should be encouraged.

\section{Institutional and Technical Capacity}

Institutions or agencies are government's tools for bringing leadership goals to the people. In the event of crises, these agencies coordinate activities ranging from rescues and recovery to building back for victims. In the DCs, it is argued that these agencies are weak while their roles are not clearly defined (Nkwunonwo et al., 2015b). Similarly, technical capacity is insufficient. This implies some limitation to what can be achieved. For example data paucity is a serious condition in the DCs, yet researchers seem to be at a loss over which agency should be responsible. In the UK, the Environment Agency is responsible for data and other disaster related issues at the national level (Pitt, 2008). Similarly, FEMA and Rijkswaterstaat are responsible for flood management in the United States and Netherlands respectively. The operational techniques of these agencies simplify the gaps between various chains of commands and speed up operation so that much is achieved within limited time. This robustness is evidenced in the attention urban flooding has received over the years. Technical capacity is also developed through regular in-service training of staff.

For the DCs, institutional capacity is a direct opposite. The poor performance of institutions seems to suggest, inter alia, poor structure, limited funding and lack of accountability. It equally shows a high level of laxity in leadership and politics. The author contends that under such a situation, there is little technical capacity and it is difficult to address the challenges of urban flooding or related disasters. Although this situation has prevailed over time, little research has focused on the means of addressing the matter. A likely way forward will be to initiate a reassessment of the roles and achievements of institutional framework in these areas. Where there are clear reasons to suggest that an agency is redundant or underperforming, measures should be adopted to address the situation. This is a common practice in many places under the provision of the law. In Nigeria for example, a number of government institutions have either been superseded or revoked on the basis of renewed goal and objectives as well strategies for addressing burgeoning complex societal issues.

The lack of technical capacity can be addressed by considering attention to technical training a priority in these DCs. Technical education at the college level should be revived and encouraged. Young people should be encouraged to develop their potentials through scholarships and education grants. Overseas scientific trainings should also be promoted.

\section{Urban Flooding and Management in Developing Countries}

Nigeria, Mozambique and Bangladesh are examples of countries in the DCs where many communities and urban settlements are now increasingly at high risk of flooding (Hanson et al., 2011; Jonkman, 2005). Within global disaster database, reported human, economic and ecological impacts of flooding are significant (CRED, 2013). Their major cities-Lagos, Maputo and Dhaka respectively-play significant roles in globalisation and politics, human and economic development. However, a corresponding urban planning and development to mitigate the effects of widespread urban flooding is lacking (Nkwunonwo et al., 2015a). On the bases of these realities, researchers have been critical on the effectiveness of measures to tackle flooding and other hazards (Christie and Hanlon, 2001; Douglas et al., 2008; Stalenberg and Vrijling, 2009; Adelekan, 2015). 


\section{Lagos}

Lagos is a low lying coastal city located in the southeastern part of Nigeria, West Africa. The city, although relatively small in land mass, with a population of nearly 20 million people is the largest in Nigeria and qualified as one of the mega cities in the world. With a range of transportation network, several commercial activities, strategic utilities and urban infrastructure, including the harbour, the city serves as a major economic hub for Nigeria and many African countries. Urban flooding which reoccurs annually during the rainy season remains a major factor militating against sustainable development. An example of these frequent low magnitude events is the July 2011 urban flooding which affected more than five thousand people with about 25 deaths and economic loss that reached 30 billion Nigerian Naira (US\$ 320 million). Public utilities including network of roads, bridges and schools were destroyed. Houses collapsed, private homes were submerged, while personal cars were swept away by flood water (IFRC, 2012; Oladunjoye, 2011). To highlight the magnitude of the threats, a report was released by a Vanguard of July 12th 2011 with the caption, "Lagosian are counting their losses".

Ample studies suggest that climate change and poor urban planning are the main causes of urban flooding in Lagos (Adeloye and Rustum, 2011; Aderogba, 2012). Talking about climate change (Odjugo, 2006) investigated significant variations in rainfall since the last three decades. The study showed that there are now more high intensity short duration rainfall and low intensity long duration than there were one or two decades ago. Poor drainage facilities in Lagos which Aderogba (2012) investigated clearly indicates poor urban planning. Various roads and streets of Lagos are aligned side by side with drainage systems, but many of them are blocked by debris or covered with unplanned structures. Besides, they are easily overwhelmed by rainfall events. Although various political leaderships have prioritized sustainable drainage systems for Lagos, but the fulfillment of the objective seems to be undermined by transitions in leadership.

The means of tackling urban flooding in Lagos has received some attention in research literature, in politics and international collaborations. Structural measures such as chennelisation of various canals, bridges, culverts and drainage systems to evacuate more storm water are acknowledged (Adelekan, 2015). Humanitarian aids (from for examples: Religious bodies, international communities, the United Nations, foreign agents), have been prominent all along (Nkwunonwo et al., 2015b). Local planning authorities legislate against illegal structures and enforce that more building conform to local building standards. However, these efforts have been criticized as limited and unable to address the increasing challenges of urban flooding. Poor awareness of flooding among the wider population prevails (Oloke et al., 2013). Institutional framework is poorly administered and the efforts generally appear to skimp more robust and more scientific approaches such as flood modelling and assessment of vulnerability to flooding (Adelekan, 2015; Nkwunonwo et al., 2015b).

\section{Maputo}

Flooding in Mozambique, a country in southeast African, clarifies three significant issues in relation to climate related events. These include the vulnerability of coastal areas especially in the DCs, environmentally induced resettlement caused by disasters and the persistent efforts of a government to balance the safety of threatened people with the need to earn livelihoods on floodplains (Stal, 2011). In Africa, Mozambique shares a similar experience with Nigeria, Algeria and Ethiopia in terms of annual recurrence of flooding and the high level of impacts (Nkwunonwo et al., 2015a). Although sparsely populated, Mozambique flooding impacts largely on agriculture which seems to be the mainstay of the nation's Gross Domestic Product (GDP). Of all the major cities in Mozambique, Maputo, which is the capital and largest city, experiences a relatively higher rate of urban growth. This implies an increased risk of urban flooding. Despite this uncertainty, the city plays significant roles in the country's economic development. Mozambique's base for manufacturing of cement, pottery, furniture, shoes and rubber and exporting sugar, chromites, sisal, copra and hardwood is located in Maputo.

Maputo, located in the southern part of Mozambique is the country's port city on the Indian Ocean. The city has a population of nearly 1.8 million with a relatively short rainy season lasting from November through March. Although much of severe flooding in Maputo occurred in the early 1980's, the poor urban development of the city in relation to its growth rouses concern for preparedness in view of future flood disaster. A major reason for this stems from the year 2000 flooding which remains a historic event. Mozambique experienced severe flooding (referred to as the worst in 50 years), that affected about 4.5 million people and cost approximately $20 \%$ of the country's GDP. Whilst much of these flooding events were influenced by Rivers Zambezi and Limpopo, however, the combination of global warming especially in increased frequency and intensity of rainfall and sea-level rise escalate the city's vulnerability to worsened risk of flooding events.

Structural measures have been prominent in the flood management system within Maputo and Mozambique in general. However, the need for lessened vulnerability to flooding and improved preparedness prompts debates towards adopting integrated approaches and best practices in flood risk reduction (Lumbroso et al., 2008). 
Carmo Vaz (2000) claimed that non-structural measures are difficult to implement in Mozambique due to inadequate financial and human resources. Preparedness is far from standard. With a complex chain of command, stretching through the National Directorate for Territorial Planning (DNOPT), the District Administrators, the Provincial Governors, the Minister for the area that controls the specific activity proposed to be developed in the flood plain, it is difficult to define who makes decision towards flood plain management in Mozambique. This largely constrains efforts to tackle flooding.

\section{Dhaka}

Floods have caused devastation in Bangladesh all through history, especially during the years 1966, 1987, 19881998 and 2007. It is worthy of note that $75 \%$ of Bangladesh is less than $10 \mathrm{~m}$ above sea level and $80 \%$ is flood plain. Therefore the risk of flooding for the country with a fast growing population (most of whom are poor and whose livelihood depend almost entirely on agriculture) is undeniably high. In a typical year in Bangladesh, flooding normally occurs during the monsoon season from June to September affecting about $26,000 \mathrm{~km}^{2}$, (around $18 \%$ ) of the country, killing over 5,000 people and destroying more than 7 million homes (Brouwer et al., 2007). Such floods are produced by the convectional rainfall of the monsoon cum relief rainfall caused by the Himalayas and major cities are at extremely high risk.

Dhaka, the capital of Bangladesh, is one of the cities at a high risk of urban flooding. The city grew strongly between 2001 and 2011 and is by far the most densely populated urban area in the world (WB, 2013). The city's population density is estimated at 115,000 per square mile or 44,000 per square kilometer, with slum (informal dwelling) densities estimated at 4,210 per acre, or 2.7 million per square mile (1 million per square kilometer). In Dhaka Metropolitan area water logging is a common experience. Certain areas of the city can be inundated for several days following a short duration low intensity rainfall. The water depth in some of the inundated areas may be as high as $0.5 \mathrm{~m}$. This can have significant impacts of human and economic resources.

Flood risk management in Dhaka takes the form of structural and non-structural measures. In terms of the structural measures, flood protection embankment along the river Buriganga is acknowledged (Huq and Aslam, 2003). Flood modelling and other form of non-structural measures are practicable but at a limited capacity. It is argued that what is most unfortunate about Bangladesh's critical flooding situation is the fact that its people are those who are least responsible for global warming (Huq and Aslam, 2003). Economic activities in Bangladesh result in almost negligible contribution to the global climate change. Despite this the country experiences unfortunate circumstance due to the occurrence of one of the worst climate events. However, there are unique flood adaptation strategies. These include two distinct initiatives which are fascinating. (1) 'Cluster village' which is elevated building in which houses are built on platforms elevated above the highest possible water level during flooding and (2) 'Floating schools', in which school classrooms are constructed on boats with the aim to enable provision of education for children who have been torn apart and whose education have been disrupted by flood catastrophes. This tale of commitment in Bangladesh however requires beefing up relevant capacities for future resilience to flooding.

\section{Conclusion}

Urban flooding is a major environmental hazard that threatens many cities across the world. Driven mainly by climate change and poor urban planning, its impacts are significant especially in the rapidly growing urban areas in Developing Countries (DCs) such as Nigeria and Bangladesh. This is due to the large number of people and assets within the cities. For reasons that border on the economic and political importance of cities, finding solution to the challenges of urban flooding is increasingly an issue of global concern, which within the context of sustainable human and urban development is a major problem in social sciences research. Integrated flood risk management approaches based on the idea of living with flood rather than fighting them and this have been extensively applied to tackle urban flooding in many developed countries such as the United States, Netherlands and UK. This involved structural and nonstructural measures aimed at reducing flood hazard occurrence, exposure of social systems and their vulnerabilities. Flood risk and flood hazard map used to create awareness of flooding in the wider population and to inform the decision of stake holders are major features.

The management of urban flooding in the DCs raises strong debates. Ongoing measures such as efforts by the government and other stake holders are aimed to merely control flooding rather than promote adaptation. Indeed, these measures are fragmented approaches which attempt to reduce the complexity of the problem by subdividing it into manageable subsets and providing provisional solution on the bases of resources that are handy. However, they are limited efforts which highlight various insufficient or lacking capacities. These include economic, social, research, juridical and political as well as institutional and technical capacities.

The discussion presented here explores these capacities, their origins and how they influence flood risk management in the DCs. Placing the developed countries side-by-side the DCs, there are clear fascinating distinctions in flood risk management. Most 
importantly, regional collaborations, human commitment, institutional robustness, strong legislative acts and a determination to positively "write the wrongs" in a history are fundamental. Within the context of sustainable development, this presents a strong challenge to the DCs. For these countries, the author argues that urban flood risk management remains an abstract concept since it is practised within the context of revived political commitment. In the context in which it is practised, opportunities to influence significant and positive change are not recognized within administrative and policy frameworks.

Despite these flaws, there are lots of potential within the DCs which can drive best practices in flood risk management in the future. Thus the study recognizes the importance of awakened consciences, responsible government and people, research and funding. It also recognizes that the exploratory discussion on these specific capacities was not on the basis of any empirical investigation. This means that the uncertainties are large and significant which is a major limitation to the study. Future studies that will investigate these capacities and how they vary across spatial and temporal scales within the framework of the DCs are recommended.

\section{Recommendation}

Many DCs are at a dead-end with regards to tackling urban flooding. Inadequate sustainable drainage systems, poor awareness of urban flooding, paucity of data for more empirical investigation of urban flooding and weak institutional framework are typical factors that constrain urban flood management in such places. Little wonder the impacts of urban flooding are more severe, an issue which is a major cause of concern within the context of sustainable development (Daramola and Ibem, 2010). Under the circumstances of worsened future flood risk, it is argued that for the DCs to make substantial progress in tackling urban flooding, among other requirements, urgent needs in environmental management must be met. Moreover, issues in political transparency and stability, in addition to respect for human right and freedom that undermine positive objectives such as development of pertinent capacities must be addressed on the basis of awakened consciences.

From the issues emerging from this study, it can be argued that at the heart of all possible causes of escalating threats of urban flooding and the limitations or failure to address them in the DCs, is the lack of pertinent capacities. Although there have been provisional actions, they are feeble and insufficient compared to the magnitude of threats that confront these places. For social systems to cope with floods, the importance of socio-economic capacities should not be undermined. To reduce widespread vulnerability, residential and commercial houses need to be reinforced and this would require a minimum amount of engineering and technical capacity. For the efficiency of urban drainage systems to be improved along with structures that contain hydrological perturbations, it is important that capacities which are relevant to understanding the quality implications of these structures are put in place.

Exploring the inadequacy or lack of these capacities can make significant contributions to knowledge towards addressing the challenges of urban flooding in these areas. However, on the basis of best practices in flood risk management, inclusion of more robust and more scientific approaches such as flood modelling is supported and recommended for the DCs. Additionally, the importance of awakened consciences, responsible government and people, research and funding are emphasized.

\section{Acknowledgement}

This is part of an ongoing effort to advance current knowledge in the management of flooding in the whole of Nigeria. Part of the funds came from first author's research grant by the UNN Tertiary Education Intervention Fund (TET Fund). Data relating to flooding were sourced mainly from the Center for Research in Epidemiology of Disasters (CRED). Previous works in this area are equally acknowledged and so are the anonymous reviewers of this paper.

\section{Author's Contributions}

Nkwunonwo Ugonna Chimnonyerem: Designed the study and wrote the initial draft.

Nkwunonwo Ugochi Adannaya: Undertook the secondary data collection, synthesised the literature and reviewed the original draft.

Chiemelu Emmanuel Ndukwe: Reviewed the original draft and made critical observations and contributions. All authors gave approval of the final submitted version.

\section{Ethics}

This study reports original findings, which make contribution to the science of flood risk management. The contents are the views of the authors and not necessarily the journal publishers. The research has never been published elsewhere or is it being considered for publication in any other journal.

\section{References}

Action Aid, 2006. Climate change, urban flooding and the rights of the urban poor in Africa: Key findings from six African cities. Action Aid International, London. 
Adams, R.H. and J. Page, 2005. Do international migration and remittances reduce poverty in developing countries?. World Develop., 33: 1645-1669.

DOI: 10.1016/j.worlddev.2005.05.004

Adelekan, I.O., 2015. Flood risk management in the coastal city of Lagos, Nigeria. J. Flood Risk Manage. DOI: 10.1111/jfr3.12179

Adeloye, A.J. and R. Rustum, 2011. Lagos (Nigeria) flooding and influence of urban planning. Urban Design Plann., 164: 175-187.

DOI: $10.1680 /$ udap. 1000014

Aderogba, K.A., 2012. Global warming and challenges of floods in Lagos metropolis, Nigeria. Acad. Res. Int., 2: 448-468.

Alberti, M., 2005. The effects of urban patterns on ecosystem function. Int. Regional Sci. Rev., 28: 168-192. DOI: 10.1177/0160017605275160

Ashley, R., S. Garvin, E. Pasche, A. Vassilopoulos and C. Zevenbergen, 2007. Advances in Urban Flood Management. 1st Edn., CRC Press, ISBN-10: 0203945980, pp: 512.

Ashley, R., D. Balmforth, A. Saul and J. Blanskby, 2005. Flooding in the future--predicting climate change, risks and responses in urban areas. Water Sci. Technol., 52: 265-273. PMID: 16248204

Brouwer, R., S. Akter, L. Brander and E. Haque, 2007. Socioeconomic vulnerability and adaptation to environmental risk: A case study of climate change and flooding in Bangladesh. Risk Anal., 27: 313326. DOI: 10.1111/j.1539-6924.2007.00884.x

Brown, J.D. and S.L. Damery, 2002. Managing flood risk in the UK: Towards an integration of social and technical perspectives. Trans. Inst. Br. Geographers, 27: 412-426. DOI: 10.1111/1475-5661.00063

Brulle, R.J. and D.N. Pellow, 2006. Environmental justice: Human health and environmental inequalities. Ann. Rev. Public Health, 27: 103-124. DOI: 10.1146/annurev.publhealth.27.021405.102124

Butler, D. and J.W. Davies, 2010. Urban Drainage. 3rd Edn., CRC Press, ISBN-10: 0203849051, pp: 632.

Carmo Vaz, Á., 2000. Coping with Floods: The Experience of Mozambique. In: Sustainable use of Water Resources: Advances in Education and Research, WARFSA, pp: 1-15.

Chen, S. and M. Ravallion, 2007. Absolute poverty measures for the developing world, 1981-2004. Proc. National Acad. Sci., 104: 16757-16762. DOI: 10.1073/pnas.0702930104

Chou, C., J.C. Chiang, C.W. Lan, C.H. Chung and Y.C. Liao et al., 2013. Increase in the range between wet and dry season precipitation. Nature Geosci., 6: 263-267. DOI: 10.1038/ngeo 1744

Christie, F. and J. Hanlon, 2001. Mozambique \& the Great Flood of 2000. 1st Edn., Indiana University Press, Oxford, ISBN-10: 0253339782, pp: 176.
CRED, 2013. Annual Disaster Statistical Review 2012: The Numbers and Trends. In: Brussels, Guha-Sapir, D., P. Hoyois and R. Below (Eds.).

Daramola, A. and E.O. Ibem, 2010. Urban environmental problems in Nigeria: Implications for sustainable development. J. Sustainable Develop. Afr., 12: 124-145.

Dawson, R.J., L. Speight, J.W. Hall, S. Djordjevic and D. Savic et al., 2008. Attribution of flood risk in urban areas. J. Hydroinformat., 10: 275-288. DOI: 10.2166 /hydro.2008.054

DEFRA, 2013. Desktop review of 2D hydraulic modelling packages. Department for Environment Food and Rural Affairs.

DeFries, R. and K.N. Eshleman, 2004. Land-use change and hydrologic processes: A major focus for the future. Hydrol. Process., 18: 2183-2186. DOI: $10.1002 /$ hyp. 5584

De Moel, H., J. van Alphen and J.C. Aerts, 2009. Flood maps in Europe-methods, availability and use. Natural Hazards Earth Syst. Sci., 9: 289-301. DOI: 10.5194/nhess-9-289-2009

Di Baldassarre, G. and S. Uhlenbrook, 2012. Is the current flood of data enough? A treatise on research needs for the improvement of flood modelling. Hydrol. Process., 26: 153-158. DOI: $10.1002 /$ hyp. 8226

Djankov, S., E. Glaeser, R. La Porta, F. Lopez-deSilanes and A. Shleifer, 2003. The new comparative economics. J. Comparative Econom., 31: 595-619. DOI: $10.1016 /$ j.jce.2003.08.005

Djordjevic, S., D. Butler, P. Gourbesville, O. Mark and E. Pasche, 2011. New policies to deal with climate change and other drivers impacting on resilience to flooding in urban areas: The CORFU approach. Environ. Sci. Policy, 14: 864-873. DOI: $10.1016 /$ j.envsci.2011.05.008

DLR, 2005. Uncrewed urban disaster relief-rescue exercise in a simulated flood.

Dore, M.H., 2005. Climate change and changes in global precipitation patterns: What do we know? Environ. Int., 31: 1167-1181. DOI: 10.1016/j.envint.2005.03.004

Douglas, I., K. Alam, M. Maghenda, Y. Mcdonnell and L. McLean et al., 2008. Unjust waters: Climate change, flooding and the urban poor in Africa. Environ. Urbanizat., 20: 187-205. DOI: $10.1177 / 0956247808089156$

EC, 2004. Flood risk management-flood prevention, protection and mitigation. European Commission.

Ecns.cn, 2016. Urban flooding prevention urgent. Ecns.cn.

FEMA, 1992. Floodplain management in the United States: An assessment report: Volume 1: summary. Federal Emergency Management Agency. 
FEMA, 1999. Protecting building utilities from flood damage: Principles and practices for the design and construction of flood resistant building utility systems. Federal Emergency Management Agency.

Few, R., 2003. Flooding, vulnerability and coping strategies: Local responses to a global threat. Prog. Develop. Stud, 3: 43-58. DOI: 10.1191/1464993403ps049ra

Fratini, C.F., G.D. Geldof, J. Kluck and P.S. Mikkelsen, 2012. Three Points Approach (3PA) for urban flood risk management: A tool to support climate change adaptation through transdisciplinarity and multifunctionality. Urban Water J., 9: 317-331. DOI: $10.1080 / 1573062 X .2012 .668913$

Freeman, M., 2008. Democracy, Al Qaeda and the causes of terrorism: A strategic analysis of U.S. policy. Stud. Conf. Terrorism, 31: 40-59. DOI: $10.1080 / 10576100701759996$

Galloway, G.E., 2008. Flood risk management in the United States and the impact of Hurricane Katrina. Int. J. River Basin Manage., 6: 301-306. DOI: $10.1080 / 15715124.2008 .9635357$

Hall, J.W., I.C. Meadowcroft, P.B. Sayers and M.E. Bramley, 2003. Integrated flood risk management in England and Wales. Natural Hazards Rev., 4: 126-135. DOI: 10.1061/(ASCE)1527-6988(2003)4:3(126)

Hanson, S., R. Nicholls, N. Ranger, S. Hallegatte and J. Corfee-Morlot et al., 2011. A global ranking of port cities with high exposure to climate extremes. Climatic Change, 104: 89-111. DOI: $10.1007 / \mathrm{s} 10584-010-9977-4$

Huq, S. and M. Alam, 2003. Flood Management and Vulnerability of Dhaka City. In: Building Safer Cities: The Future of Disaster Risk. Kreimer, A., M. Arnold and A. Carlin (Eds.), World Bank Publications, Washington, D.C., ISBN-10: 0821354973, pp: 121-135.

IFRC, 2012. Nigeria: Floods-July. International Federation of Red Cross and Red Crescent.

Jha, A.K., R. Bloch and J. Lamond, 2012. Cities and Flooding: A Guide to Integrated Urban Flood Risk Management for the 21st Century. 1st Edn., World Bank Publications, Washington, D.C., ISBN-10: 0821394770, pp: 632.

Jonkman, S.N., 2005. Global perspectives on loss of human life caused by floods. Natural Hazards, 34: 151-175. DOI: $10.1007 / \mathrm{s} 11069-004-8891-3$

Krieger, T. and D. Meierrieks, 2011. What causes terrorism? Public Choice, 147: 3-27.

DOI: $10.1007 / \mathrm{s} 11127-010-9601-1$

Kundzewicz, Z.W., S. Kanae, S.I. Seneviratne, J. Handmer and N. Nicholls et al., 2014. Flood risk and climate change: Global and regional perspectives. Hydrol. Sci. J., 59: 1-28. DOI: 10.1080/02626667.2013.857411
Li, Q. and A. Resnick, 2003. Reversal of fortunes: Democratic institutions and foreign direct investment inflows to developing countries. Int. Organ., 57: 175-211. DOI: $10.1017 / \mathrm{S} 0020818303571077$

Lichterman, P., 2006. Social capital or group style? Rescuing Tocqueville's insights on civic engagement. Theory Society, 35: 529-563. DOI: $10.1007 / \mathrm{s} 11186-006-9017-6$

Lichterman, P., 2009. Social capacity and the styles of group life some inconvenient wellsprings of democracy. Am. Behav. Sci., 52: 846-866. DOI: $10.1177 / 0002764208327662$

Lumbroso, D., D. Ramsbottom and M. Spaliveiro, 2008. Sustainable flood risk management strategies to reduce rural communities' vulnerability to flooding in Mozambique. J. Flood Risk Manage., 1: 34-42. DOI: 10.1111/j.1753-318X.2008.00005.X

Lyons, M.J., 2009. World War II: A Short History. 5th Edn., Prentice Hall, Boston, ISBN-10: 0205660568, pp: 328.

Marvel, K. and C. Bonfils, 2013. Identifying external influences on global precipitation. Proc. National Acad. Sci., 110: 19301-19306. DOI: $10.1073 /$ pnas.1314382110

Meesuk, V., Z. Vojinovic, A.E. Mynett and A.F. Abdullah, 2015. Urban flood modelling combining top-view LiDAR data with ground-view SfM observations. Adv. Water Resour., 75: 105-117. DOI: 10.1016/j.advwatres.2014.11.008

Merz, B., A.H. Thieken and M. Gocht, 2007. Flood Risk Mapping at the Local Scale: Concepts and Challenges. In: Flood Risk Management in Europe: Innovation in Policy and Practice, Begum, S., M.J.F. Stive and J.W. Hall (EDs.), Springer Science and Business Media, Dordrecht, ISBN-10: 1402042000, pp: 231-251.

Merz, B., H. Kreibich, R. Schwarze and A. Thieken, 2010a. Review article "Assessment of economic flood damage". Natural Hazards Earth Syst. Sci., 10: 1697-1724. DOI: 10.5194/nhess-10-1697-2010

Merz, B., J. Hall, M. Disse and A. Schumann, 2010 b. Fluvial flood risk management in a changing world. Natural Hazards Earth Syst. Sci., 10: 509-527. DOI: 10.5194/nhess-10-509-2010

Min, S.K., X. Zhang, F.W. Zwiers and G.C. Hegerl, 2011. Human contribution to more-intense precipitation extremes. Nature, 470: 378-381. DOI: $10.1038 /$ nature 09763

Nakagawa, Y. and R. Shaw, 2004. Social capital: A missing link to disaster recovery. Int. J. Mass Emergencies Dis., 22: 5-34.

Nicholls, R., J.S. Hanson, C. Herweijer, N. Patmore and S. Hallegatte et al., 2008. Ranking port cities with high exposure and vulnerability to climate extremes. University of Southampton, United Kingdom. DOI: $10.1787 / 19970900$ 
Nkwunonwo, U.C., W. Malcolm and B. Brain, 2015a. Flooding and flood risk reduction in Nigeria: Cardinal gaps. J. Geography Natural Hazards, 5: 1-12. DOI: $10.4172 / 2167-0587.1000136$

Nkwunonwo, U.C., W. Malcolm and B. Brain, 2015b. A review of urban flooding and a critical analysis of efforts towards urban flood reduction in the Lagos region of Nigeria. Natural Hazards Earth Syst. Sci. Discuss., 3: 3897-3923.

Nkwunonwo, U.C., W. Malcolm and B. Brain, 2016. A review and critical analysis of the efforts towards urban flood risk management in the Lagos region of Nigeria. Natural Hazards Earth Syst. Sci., 16: 349-369. DOI: 10.5194/nhess-16-349-2016

Newman, E., 2006. Exploring the "root causes" of terrorism. Stud. Conf. Terrorism, 29: 749-772. DOI: 10.1080/10576100600704069

Odjugo, P.A.O., 2006. An analysis of rainfall pattern in Nigeria. Global J. Environ. Sci., 4: 139-145.

Oladunjoye, M., 2011. Nigeria: July 10 Flooding-Lagos gives relief materials to victims. Daily Champion Newspaper.

Oloke, O.C., K.C. Ijasan, A.O. Ogunde, L.M. Amusan and P.F. Tunji-Olayeni, 2013. Improving urban residents' awareness of the impact of household activities on climate change in Lagos state, Nigeria. J. Sustainable Develop., 6: 56-69. DOI: $10.5539 /$ jsd.v6n4p56

Pitt, M., 2008. Lessons from the 2007 Floods. 1st Edn., Pitt Review, London.

POST, 2007. Post note: Urban flooding. Parliamentary Office of Science and Technology.

Penning-Rowsell, E., C. Johnson, S. Tunstall, S. Tapsell and J. Morris et al., 2005. The benefits of flood and coastal risk management: A handbook of assessment techniques. Middlesex University Press.

Price, R.K. and Z. Vojinovic, 2008. Urban flood disaster management. Urban Water J., 5: 259-276. DOI: $10.1080 / 15730620802099721$

Ravallion, M., 2001. Growth, inequality and poverty: Looking beyond averages. World Develop., 29: 1803-1815. DOI: 10.1016/S0305-750X(01)00072-9

Rykhus, R.P., 2005. Satellite imagery maps Hurricane Katrina-induced flooding and oil slicks. Trans. Am. Geophys. Union, 86: 381-382.

DOI: $10.1029 / 2005 E O 410003$

Sampson, C.C., P.D. Bates, J.C. Neal and M.S. Horritt, 2013. An automated routing methodology to enable direct rainfall in high resolution shallow water models. Hydrol. Process., 27: 467-476.

DOI: 10.1002/hyp.9515

Sayers, P., Y. Li, G. Galloway, E. Penning-Rowsell and F. Shen et al., 2013. Flood risk management: A strategic approach. Paris, UNESCO.
Schanze, J., 2006. Flood Risk Management-A Basic Framework. In: Flood Risk Management: Hazards, Vulnerability and Mitigation Measures, Schanze, J., E. Zeman and J. Marsalek (Eds.), Springer Netherlands, Dordrecht, ISBN-10: 1402045972, pp: 1-20.

Schlosberg, D., 2007. Defining Environmental Justice: Theories, Movements and Nature: Theories, Movements and Nature. 1st Edn., OUP Oxford, Oxford, ISBN-10: 0199286299, pp: 256.

Smith, K., 2013. Environmental Hazards: Assessing Risk and Reducing Disaster. 6th Edn., Routledge, London, ISBN-10: 0415681057, pp: 478.

Stal, M., 2011. Flooding and relocation: The Zambezi river valley in Mozambique. Int. Migrat., 49: e125-e145. DOI: 10.1111/j.1468-2435.2010.00667.x

Stalenberg, B. and H.A.N. Vrijling, 2009. The battle of Tokyo and Dhaka against floods. Built Environ., 35: 471-491. DOI: 10.2148/benv.35.4.471

Tayeb, M., 2001. Conducting research across cultures: Overcoming drawbacks and obstacles. Int. J. Cross Cultural Manage., 1: 91-108. DOI: $10.1177 / 147059580111009$

Tingsanchali, T., 2012. Urban flood disaster management. Proc. Eng., 32: 25-37. DOI: $10.1016 /$ j.proeng.2012.01.1233

Terpstra, T. and J.M. Gutteling, 2008. Households' perceived responsibilities in flood risk management in the Netherlands. Int. J. Water Resour. Develop., 24: 555-565. DOI: $10.1080 / 07900620801923385$

Un-Habitat, 2008. State of the World's Cities 2008-2009: Harmonious Cities. 1st Edn., Earthscan, London, ISBN-10: 1844076954, pp: 264.

UNISDR, 2004. Living with Risk: A Global Review of Disaster Reduction Initiatives. 1st Edn., UN, New York, ISBN-10: 9211010640, pp: 555.

UNISDR, 2010. Making cities resilient: My city is getting ready, 2010-2011. International Strategy for Disaster Reduction.

USEPA, 1983. Result of the national urban runoff project (final report). United States Environmental Protection Agency, Washington DC.

van Ogtrop, F.F., A.Y. Hoekstra and F. van der Meulen, 2005. Flood management in the lower Incomati River Basin, Mozambique: Two alternatives. J. Am. Water Resour. Associat., 41: 607-619. DOI: 10.1111/j.1752-1688.2005.tb03758.x

Vis, M., F. Klijn, K.M. De Bruijn and M. Van Buuren, 2003. Resilience strategies for flood risk management in the Netherlands. Int. J. River Basin Manage., 1: 33-40. DOI: $10.1080 / 15715124.2003 .9635190$

Walther, G.P., E. Post, P. Convey, A. Menzel and C. Parmesan et al., 2002. Ecological responses to recent climate change. Nature, 416: 389-395. PMID: 11919621 
WB, 2013. World Bank Population growth rate 20092013. World Bank.

Weng, Q., 2001. Modeling urban growth effects on surface runoff with the integration of remote sensing and GIS. Environ. Manage., 28: 737-748. PMID: 11915963.
Woods-Ballard, B., R. Kellagher, P. Martin, C. Jefferies and R. Bray et al., 2007. The SUDS Manual. 1st Edn., Construction Industry Research and Information Association, London, ISBN-10: 0860176975, pp: 600. 